Re-Writing in the Margins: Caro's Valor, agravio y mujer as Challenge to Dominant

Discourse

By: Amy R. Williamsen

Williamsen, Amy R. "Re-writing in the Margins: Caro's Valor, agravio y mujer as Challenge to Dominant Discourse." Bulletin of the Comediantes 44.1 (1992): 21-30.

Made available courtesy of Bulletin of Comediantes: http://www.comediantes.org/

***(C) The Author. Reprinted with permission. No further reproduction is authorized without written permission from the author \& Bulletin of Comediantes. ***

\begin{abstract}
:
The title of this paper deliberately establishes a dialogic relationship with Paul Julian Smith's work Writing in the Margin; at the same time, it suggests the possibility of the "re"-writing of dominant discourse in marginalized works. The concept of marginality holds significant implications for the consideration of literature beyond those directly addressed in Smith's work. In this discussion, I will use Ana Caro's comedia, Valor, agravio y mujer, to question assumptions underlying Smith's provocative treatise. His interpretive strategy, informed by poststructuralist theory, does not sufficiently allow for the challenge to both social and artistic norms posed by the self-conscious, metatheatrical elements of Golden Age theatre. The constant play with gender roles and the honor code in Caro's texts represents a rewriting of societal standards; moreover, her consistent manipulation of generic conventions critically engages "canonical" comedias. I will argue that in order to explore "writing in the margin" we must carefully consider works that have been marginalized; otherwise, we as critics may falsely claim to appropriate the place of "the Others," thereby propagating exclusionary practices that merely re-center rather than de-center discourse.
\end{abstract}

Keywords: Spanish Golden Age Theatre | Literary Criticism | Theater

***Note: Full text of article below 


\title{
RE-WRITING IN THE MARGINS: CARO'S VALOR, AGRAVIO Y MUJER AS CHALLENGE TO DOMINANT DISCOURSE
}

\author{
AMY R. WILLIAMSEN \\ University of Arizona
}

The title of this paper deliberately establishes a dialogic relationship with Paul Julian Smith's work Writing in the Margin; at the same time, it suggests the possibility of the "re"-writing of dominant discourse in marginalized works. ${ }^{1}$ The concept of marginality holds significant implications for the consideration of literature beyond those directly addressed in Smith's work. In this discussion, I will use Ana Caro's comedia, Valor, agravio y mujer, to question assumptions underlying Smith's provocative treatise. His interpretive strategy, informed by post-structuralist theory, does not sufficiently allow for the challenge to both social and artistic norms posed by the self-conscious, metatheatrical elements of Golden Age theatre. The constant play with gender roles and the honor code in Caro's texts represents a rewriting of societal standards; moreover, her consistent manipulation of generic conventions critically engages "canonical” comedias. I will argue that in order to explore "writing in the margin" we must carefully consider works that have been marginalized; otherwise, we as critics may falsely claim to appropriate the place of "the Other", thereby propagating exclusionary practices that merely re-center rather than de-center discourse.

At times, Smith's theoretical virtuosity, demonstrated throughout his various works, can obscure crucial political implications of his interpretations. In Writing in the Margin, for example, he proposes that Spain and Spanish literature remain marginal to Europe, an assertion that inherently contains traces of the leyenda negra. In his conclusion, he affirms: 
... the particular significance of Spain and its Renaissance writers might be as an example of persistent and irreducible marginality. For Spain is the 'woman' of European culture...Like the concept of 'woman' under patriarchy, Spain embodies that lack on which Law is predicated, [and] serves as the term which can neither be excluded from the system, nor allowed to participate in it. (204-5)

This quotation raises many questions for it implicitly reproduces an injurious politics of exclusion without challenging the operant dynamic. One might argue that by calling attention to the problem Smith has begun to challenge the dominant system; yet, as Gayatri Chakravorty Spivak contends, "The putative center welcomes selective inhabitants of the margin in order to better exclude the margin. And it is the center that offers the official explanation..." (107). By defining the canonical works of the Spanish Renaissance as marginal to European literature, the critic effectively displaces those works considered "marginal" within Spanish literature, further distancing them from the center.

The use of woman as metaphor proves perhaps even more disturbing. Elizabeth Grosz examines this same problematic practice in Derrida:

As metaphor, "woman" may well function as a disrupting, disturbing unassimilable element in all logo- and phallocentric texts, but nonetheless it is also the name (albeit an improper one) for women. To affirm the metaphor may... effectively silence women. (36)

Moreover, Smith's "Lacanian" equation of woman with lack fails to acknowledge Irigaray's plea for the "problematization" of "representational systems marking women's bodies as lacking, dependent [and] oriented toward the phallus"' (Grosz, 109). (As I will explore later, Ana Caro's text itself plays with this very construction of woman.)

Revealingly, throughout the development of his argument in Writing in the Margin, Smith explicitly limits himself to canonical texts. When he speaks of the exclusions that this strategy implies, he only acknowledges the omissions of certain genres such as the cancionero, chivalric and pastoral narratives. He makes no mention of the exclusion of "minor" authors, women writers and other "marginal" figures. Smith discusses the process of canon formation through critical attention to "great works" and laudably suggests that he would hope for the "dissolution of the canon and the emergence of a 
less rigid domain of cultural studies" (7). Yet, he himself replicates the silencing of "dissident" voices.

Even when Smith does consider "Writing Women in the Golden Age" in his second book, The Body Hispanic, his interpretations occasionally violate the texts considered. In his discussion of María de Zayas, for example, he diminishes the subversive force of her narratives through a revealing mis-reading. When dealing with "Al fin se paga todo," a novella that challenges patriarchal order, as well as the critical interpretation that Zayas adheres to a strictly codified definition of honor in all her works, Smith states:

Thus Hipólita...plunges her dagger 'five or six times' into the heart of her sleeping husband...Zayas implies an acceptance of the patriarchal code of honour and does not question the belief that blood can only be cleansed with blood. Women are thus permitted to adopt a travesty of man, but cannot transgress the law of the dagger and the phallus. (Body 33)

Here Smith fails to notice the suggestive usurpation of male power embodied by the phallic symbol. The dagger Hipólita employs is her husband's, a weapon she turns against her rapist-her brother-in-law, not her spouse. As traditionally presented in Golden Age literature, the honor code would call for Hipólita's husband to kill her so that her blood could cleanse the stain on his honor. Instead, she avenges her own, not her husband's, honor. The repetition of the title at the tale's conclusion further underscores the subversion of societal norms in the work for only the men in the narrative appear subject to the retribution alluded to in the phrase "Al fin se paga todo." 2 Despite the intriguing premise of his study, Smith's inattention to the text itself propagates the silencing of Zayas' voice, thereby further marginalizing women writers in a study that claims to privilege their texts.

In his consideration of the comedia, Smith also makes assertions that can be challenged through the careful consideration of women-authored texts. His concluding remarks in the chapter on the comedia seem to posit a hegemonic audience that would respond uniformly:

Nature, desire and honour can no longer be taken for granted: they are made strange or defamiliarized. But contrary to the opinion of many critics, this is not a[n] ... 'alienation effect', cleverly contrived by the author and greedily consumed by the spectator. The peculiarities of any genre are always renaturalized by a will- 
ing audience, however non-naturalistic those generic conventions may be. (156)

Reception theory has underscored the necessity of recognizing the potential for a plurality of responses to any given text. To ignore the diversity of audience experience privileges a limited, univocal understanding. As current experiments investigating the relationship between gender and interpretation have demonstrated, many factors contribute to divergent reactions to the same text. ${ }^{3}$ In addition, the very transitory impact Smith attributes to "defamiliarization" underestimates its power-it does not provide for the challenges to both social and artistic norms posed by the self-conscious elements of many comedias, especially marginalized ones such as Caro's Valor, agravio y mujer.

At first glance, Caro's work may appear to be a traditional rendition of the mujer vestida de hombre theme; nonetheless, as the action progresses, spectators and readers alike are forced to question social conventions most often perceived as "natural." Leonor, deceived and abandoned by Don Juan, sets out to avenge her honor. She assumes the identity of Leonardo, eventually becoming Juan's rival for the affections of Estela, his new love. Throughout the play, Leonor manipulates the actions of all the characters. Her careful direction leads those around her to the conclusion she seeks-recognition of her status as Juan's legitimate wife. ${ }^{4}$ Despite the superficial trappings of the traditional mujer varonil, Leonor's presentation in the text challenges many assumptions underlying what Teresa Soufas terms "male-dominated dramatic conventions." As she explains:

Although at first glance Caro seems to be writing like her male colleagues, using what appears to be one of their favored plots, she actually conducts a subversion from within, 'surrounded by, but not entirely lost in, largely alien textual territory,'; Leonor openly validates the authority that she and her creator claim as they fashion a message about women's worth.... (89)

In fact, the first social construction called into question is gender itself. In a strategy that anticipates Judith Butler's Gender Trouble, the play presents gender not as a physical or psychological essence but as a matter of performance. Butler states: "There is no gender identity behind the expressions of gender; ... identity is performatively constituted by the very 'expressions' that are said to be its results" (25). "That the gendered body is performative suggests that it has no ontological status apart from the various acts which constitute its reality" (136). In Valor, agravio y mujer, Ribete, the lacayo, respond- 
ing to Leonor's first discourse as a man, exclaims: "Oyéndote estoy, /y-ipor Cristo!-que he pensado / que el nuevo traje te ha dado alientos" (vv. 505-507). Leonor affirms that not only her mode of dress has changed, but her gender as well: “¡Yo soy quien soy! / Engañaste si imaginas, / Ribete, que soy mujer. / Mi agravio mudó mi ser" (vv. 508-511). The work does not present gender as constant and fixed, but rather suggests that it is subject to individual reformulations.

As previously mentioned, the text also plays with the definition of woman in terms of the lack of a phallus. When Leonor jokes with Ribete about the Countess Estela's infatuation with her "as a man," he quips:

\author{
...ciega, \\ fuego imagina sacar \\ de dos pedernales fríos. \\ ¡Qué bien se entablará \\ el fuego de amor, aunque ella \\ muestre que picada está \\ si para que se despique \\ no la puedes envidar \\ si no es de falso, por ser \\ limitado tu caudal \\ para empeño tan forzoso! (1095-1105)
}

Leonor's succinct response to his observation that she needs a false "phallus" to complete her lack proves suggestively ambiguous: "Amor de mi parte está" (v. 1106). This example also embodies the inversion of another norm: the derisive mention of female parts often used in comedias (and outside the theatre as well) to evoke laughter is replaced by disparaging remarks about male anatomy throughout the play.

One of the most revealing of the many comic allusions to male sexual organs involves Flora, a servant. She drugs Tomillo, one of the graciosos, and then explores his inert body in search of hidden gold. She comments on the various odds and ends she encounters, including a "horn":

¿Qué es aquesto? ¿Tabaquera

de cuerno? ¿Qué hermoso aliño!

Parto, al fin, de su cosecha, ;honor de su frontispicio! (vv. 2407-10)

Her final query, “¡Hombres! ¿Qué aquesto os dé gusto?” (v. 2411), in which 
she directly addresses the audience, "can only be interpreted as a woman's response to the masculine myth of feminine penis envy." 5 The overt belittling of masculine anatomy and Ribete's pointed reference to a false penis definitely subvert the traditional derision of the female body in comedia texts.

In his study of the genre, Smith affirms that "women serve as objects of exchange within a male system" (125). In Caro's work, as well as in others, women also initiate exchanges of men. Estela, to name but one example, repeatedly replaces one man with another. At the end of the work, realizing that the mate she ardently pursued was a woman, she hastily chooses another man as the object of her desire.

The double standard informing the honor code represents yet another social convention defamiliarized in Valor, agravio y mujer. At the beginning of the play, Don Juan willingly admits that he broke his promise of marriage to Leonor after satisfying his carnal desires; the noblemen listening to his exploits accept him without censure even though he boasts of his falsehoods. Nevertheless, when Leonor (acting as Leonardo) confronts him, Don Juan vows:

\author{
... Os engañáis... \\ Más cierto será que falte \\ luz a los rayos del sol \\ que dejar yo de guardarle \\ mi palabra a quien la di. (vv. 1500-1503)
}

The text makes it clear that only a word given to a fellow man, as he perceives Leonardo to be, proves binding. Promises made to women need not be kept; lies told to women do not diminish one's honor. This contrasts sharply with the devasting power held by a man's accusation that another has lied. In her application of speech act theory to $A$ secreto agravio, secreta venganza, Myra Gann illustrates that the utterance "mentis" itself irreparably damages a man's honor; Valor, agravio y mujer underscores that the force of the accusation depends on the gender of the accuser.

The work reveals the inequality underlying norms governing honor and, therefore, defamiliarizes the socially accepted convention, permitting members of the audience to perceive the injustice inherent within the system. While audience reception of this textual element might vary depending on the individual's social status, the passage undoubtedly serves the function of "laying bare" that which must remain hidden for the system to persevere unchallenged. Any interpretation of the work needs to allow for members of the audience who would not "always renaturalize" the conventions exposed. 
Besides questioning social norms, Valor, agravio y mujer reveals the artificiality of generic conventions as well. Frequent metatheatrical comments, usually voiced by the graciosos, expose the artifice of the genre at the same time that they challenge elements of the existing social order. In one of the most salient cases, Ribete exclaims:

¿Por fuerza he de ser cobarde?

¿No habrá un lacayo valiente? ...

Estoy mal con enfadosos

que introducen los graciosos

muertos de hambre y gallinas.

El que ha nacido alentado

¿no lo ha de ser si no es noble?

¿Qué? ¿No podrá serlo al doble

del caballero el crïado? (vv. 523-536)

Not only does this passage expose the generic precepts governing the portrayal of graciosos in Golden Age drama, but it also calls into question the false identification of nobility with valor.

Repeatedly in the play, characters act against type, violating the audience's expectations and revealing the arbitrariness of many assumptions considered "natural." Although the mujer varonil in the comedia often participates in duels, at times even winning them, it is unusual that Leonor actually wounds Don Juan quite severely. Her violent attack undermines the association of woman with passive nurturance and offers yet another example of the ways Caro overturns accepted conventions.

In one of the most ironically charged moments of the play, the two graciosos embark on a discussion of the "proper" role for women in society. When Tomillo queries about Madrid: "¿Qué hay en el lugar de nuevo?”, Ribete answers:

Ya es todo muy viejo allá;

sólo en esto de poetas

hay notable novedad

por innumerables, tanto

que aun quieren poetizar

las mujeres, y se atreven

a hacer comedias ya. (vv. 1173-1180)

Shocked at this inexplicable turn of events, Tomillo retorts: “'Válgame Dios! 
Pues, ¿no fuera / mejor coser e hilar? / ¿Mujeres poetas?" (vv. 1181-1183). Besides the obvious irony, Caro's inclusion of this metatheatrical aside might also be interpreted as her anticipation of resistance to her intrusion into the center of literary activity. She implicitly recognizes that society in general would perceive a woman writer as someone transgressing established boundaries. Thus, the text posits the problematic relationship between margin and center.

In fact, this brief consideration of Ana Caro's play suggests several ways that marginal texts can lend insights crucial for the understanding of the literature of a given period. Only by considering that which has been excluded from the canon can we begin to understand how the canon defines itself. Any theoretical stance which threatens to appropriate marginality for works already at the center must be examined carefully.

One of Smith's most significant observations must be kept in mind: Deconstruction, he notes, "can no longer claim to be innocent of the oppressive mastery that it sought to displace or decentre" (204). I would contend that we need to expand this metacritical awareness of the potential bias of deconstruction to all theoretical and critical approaches. The blind acceptance of any critical or theoretical work may propagate the dogmatic institutionalization of privileged approaches. Smith, who forcefully speaks out against the dogmatism and prescriptivism of former critical schools, ironically has himself become the object of "the politics of adulation". In a recent article discussing the role of theory in Hispanic literature, Inés Azar and Elias Rivers refer to Smith as the "Wunderkind" of Hispanism (96), while a session of the 1990 MLA entitled "Poststructuralist Criticism of the Comedia: Issues Raised by Paul Julian Smith's Writing in the Margin"' rendered homage to his research. Although we need to recognize his outstanding contribution to our field, it would be a disservice to Smith and to theory in general if we were to accept all his work without question. Our granting of sacred status to any mortal critics, subject to their own foibles as we are to ours, proves antithetical to the inquisitive spirit essential to the academic quest. Our greatest legacy for future comedia scholarship lies not with providing definitive answers, but rather with creating a critical milieu that privileges the question.

The more voices we include in our critical dialogue, the richer our understanding will become; Bakhtin's concept of the dialogic, for example, constitutes a productive model for academic inquiry. Instead of representing dialectical opposites, margin and center will increasingly be perceived as fluctuating, interdependent constructs. Grosz laments that "Patriarchy does not prevent women from speaking; it refuses to listen when women do not speak 'universal', that is, as men"' (126). I would hope that our future discussions of mar- 
ginality in Spanish literature would take into account the voices of women and other groups whose speech has often been appropriated by dominant discourse. Only then can we grow to understand the artificiality of many assumptions we consider natural. As I draw this article to a close, in hope of opening a continuing dialogue, let Caro's textualized voice speak for me:

\author{
Aquí, senado discreto, \\ valor, agravio y mujer \\ acaba. Pídeos su dueño \\ por mujer y por humilde, \\ que perdonéis sus defectos. (vv. 2778-82)
}

\title{
NOTES
}

1. I would like to thank Sharon Voros and Catherine Larson for their encouragement and suggestions during the preparation of this study.

2. In a forthcoming article "Challenging the Code: Honor in María de Zayas," I further examine the subversion of honor in her works.

3. There are many excellent psycholinguistic studies that examine the relationship between gender and interpretation; among these, the article by Mary Crawford and Roger Chaffin provides a good introduction to this field of inquiry.

4. For an intriguing analysis of Leonor "as an analogue for the woman writer's relationship to the patriarchal text," see Elizabeth J. Ordóñez's article (11).

5. Vern G. Williamsen discusses these and other similar examples in his paper " $L a$ mujer vestida de hombre: The Subject Redressed."

\section{WORKS CITED}

Azar, Inés and Elias L. Rivers. "Diálogo crítico: Speech Acts and Literary Theory." REH 24:1 (1990): 95-106.

Butler, Judith. Gender Trouble: Feminism and the Subversion of Identity. New York: Routledge, 1990.

Caro de Mallén, Ana. Valor, agravio y mujer. Ed. prepared by Vern G. Williamsen and María José Delgado.

Crawford, Mary and Roger Chaffin, "The Reader's Construction of Meaning: Cognitive Research on Gender and Comprehension." Gender and Reading: Essays on 
Readers, Texts and Contexts. Ed. Elizabeth Flynn and Patrocinio Schweickart. Baltimore: Johns Hopkins, 1986.

Gann, Myra. "The Performative Status of Verbal Offenses in A secreto agravio, secreta venganza." Things Done with Words: Speech Acts in Hispanic Drama.

Ed. Elias L. Rivers. Newark: Juan de la Cuesta, 1986.

Grosz, Elizabeth. Sexual Subversions. Sydney: Allen and Unwin, 1989.

Irigaray, Luce. Speculum of the Other Woman. Trans. Gillian Gill. Ithaca: Cornell, 1985.

Ordóñez, Elizabeth J. "Woman and Her Text in the Works of María de Zayas and Ana Caro." REH 19:1 (1985): 3-13.

Smith, Paul Julian. The Body Hispanic. Oxford, Clarendon, 1989. Writing in the Margin. Oxford: Clarendon, 1988.

Soufas, Teresa S. "Ana Caro's Re-evaluation of the Mujer varonil and Her Theatrics in Valor, agravio y mujer." The Preception of Women in Spanish Theater of the Golden Age. Ed. Anita K. Stoll and Dawn L. Smith. Lewisburg: Bucknell UP, 1991.

Spivak, Gayatri Chakravorty. In Other Worlds: Essays in Cultural Politics. New York: Routledge, 1988.

Williamsen, Vern G. "La mujer vestida de hombre: The Subject Redressed." Presented in El Paso, March, 1991. 